\title{
ACTUAL STATUS ASSESSMENT AND SOME RECOMMENDED SOLUTIONS TO IMPROVE THE EFFICIENCY OF PHYSICAL EDUCATION WORK AT CAN THO UNIVERSITY, VIETNAM
}

\author{
Nguyen Van Hoa ${ }^{\mathrm{i}}$ \\ Dr. Can Tho University,
} Vietnam

\begin{abstract}
:
The purpose of this study is to assess the actual status and recommend some solutions to improve the efficiency of physical education (PE) work at Can Tho University. By synthesizing documents, interviewing and processing statistics, the article has assessed the actual status of PE work through the following aspects: the actual status of training; the actual status of teacher development; the actual status of the organization of sports activities, the actual status of the facilities and the actual status of the scientific research in the field of sports at Can Tho University. At the same time, the study also proposes 5 groups of solutions corresponding to the above status, which have been approved by the Board of Directors and unit members in the medium-term plan of the Department of Physical Education of Can Tho University.
\end{abstract}

Keywords: actual status, solution, improve the efficiency of physical education work, Can Tho University

\section{Introduction}

Physical education (PE) is a pedagogical process aimed at protecting and promoting health, perfecting the body, training personality and equipping necessary motor skills for each individual in life. Fitness and physical development contribute to health education. Students' physical fitness is developed naturally and is greatly influenced by education in which PE plays a decisive role in the process of physical development and health promotion for students.

Can Tho University - the government's key graduate and undergraduate training institution in the Mekong Delta, is a cultural, scientific and technical center of the whole region. The main task of the university is training, scientific research, technology transfer for socio-economic development in the region. It has a long history of development and so far, has been 55 years of training. Currently, Can Tho University has undergone 14

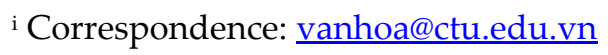


years of training under the credit system, is a multi-disciplinary - multi-vocational training university with: 19 doctoral training majors; 48 master's degree majors (01 crossborder major; 03 English majors); 109 undergraduate degrees (2 advanced programs and 8 high quality programs). Currently, the total number of learners and students of CTU is about 51,609. According to the QS announcement - "QS World University Rankings by Subjects 2020", CTU is ranked 1st in Vietnam and 251-300 in the world in the field of agriculture and forestry training.

In order to perform well the PE work and ensure that students complete their academic tasks well, the Department of Physical Education of Can Tho University has implemented a physical education program for students for many years, which makes an important contribution to students' physical development.

However, in reality, the PE work at Can Tho University has not yet achieved high efficiency. There are differences and inconsistencies in the implementation of the PE program according to the regulations of the schools, due to both subjective and objective conditions. According to the inter-sectoral statistics of the Ministry of Education and Training and the General Department of Sports and Physical Education in 2005, it shows that: "Physical education in schools at all levels is still unorganized, many schools have not yet conducted physical education in accordance with the program".

With an aim to achieving the above strategic development goals, the physical education work in schools at all levels, with its position in the country's sports development, needs to be renewed and the system of organization and implementation needs to be gradually perfected. Especially, it is crucial to improve physical education work to suit the present practice, we have chosen direction for the research with the title: "Actual status assessment and some recommended solutions to improve the efficiency of physical education work at Can Tho University".

The purpose of the article is to provide accurate and comprehensive information about the actual status, thereby proposing solutions to improve the quality of physical education work at Can Tho University.

Research methods: analyzing and synthesizing documents, interviewing and Statistical method.

Survey subjects: 5 managers from Department of Physical Education, Training Department, Department of Student Affairs.

\section{Research results}

\subsection{Assessment of the actual situation of Physical Education at Can Tho University}

To assess the current status of PE at Can Tho University, the research content presents 05 related issues about the work of PE, including: Training (specialized students and nonspecialized students in PE); teaching staff; the organization of sports activities; facilities and scientific research in sports. 


\subsection{Actual status of training}

\subsubsection{Actual status of learners and students}

Actual status of learners and students at Can Tho University at the present, stated in Table 1.

Table 1: Statistics on the actual status of students at units under

Can Tho University in the 2nd semester of the academic year 2020-2021

\begin{tabular}{|c|c|c|c|c|c|c|c|c|}
\hline \multirow[t]{2}{*}{ No } & \multirow{2}{*}{$\begin{array}{c}\text { School } \\
\text { code }\end{array}$} & \multirow{2}{*}{$\begin{array}{c}\text { Name of } \\
\text { School }\end{array}$} & \multirow[t]{2}{*}{ Total } & \multirow[t]{2}{*}{ Female } & \multicolumn{4}{|c|}{ Student Status } \\
\hline & & & & & Studying & Reserved & Graduated & $\begin{array}{c}\text { Dropped } \\
\text { out } / \\
\text { Transferred }\end{array}$ \\
\hline \multicolumn{9}{|c|}{ I. Formal university training } \\
\hline 1 & CA & $\begin{array}{l}\text { Mekong Delta } \\
\text { Development } \\
\text { Research } \\
\text { Institute }\end{array}$ & 85 & 44 & 31 & & 45 & 9 \\
\hline 2 & $\mathrm{DA}$ & $\begin{array}{l}\text { Biotechnology } \\
\text { Research and } \\
\text { Development } \\
\text { Institute }\end{array}$ & 1.262 & 801 & 1.022 & 9 & 207 & 24 \\
\hline 3 & DB & $\begin{array}{l}\text { School of Pre- } \\
\text { University }\end{array}$ & 130 & 58 & & & & 130 \\
\hline 4 & DI & $\begin{array}{l}\text { College of } \\
\text { Information } \\
\text { and } \\
\text { Communication } \\
\text { Technology }\end{array}$ & 4.810 & 1.085 & 4.214 & 13 & 409 & 174 \\
\hline 5 & FL & $\begin{array}{l}\text { School of } \\
\text { Foreign } \\
\text { Language } \\
\end{array}$ & 2,158 & 1.723 & 1.754 & 13 & 312 & 79 \\
\hline 6 & HG & $\begin{array}{l}\text { College of Rural } \\
\text { Development }\end{array}$ & 2.287 & 1.210 & 1.746 & 7 & 445 & 89 \\
\hline 7 & $\mathrm{KH}$ & $\begin{array}{l}\text { College of } \\
\text { Natural } \\
\text { Sciences }\end{array}$ & 1.216 & 744 & 995 & 5 & 171 & 45 \\
\hline 8 & KT & $\begin{array}{l}\text { School of } \\
\text { Economics }\end{array}$ & 6.932 & 5.206 & 5.532 & 36 & 1.172 & 192 \\
\hline 9 & LK & School of Law & 1.679 & 1.080 & 1.245 & 9 & 362 & 63 \\
\hline 10 & ML & $\begin{array}{l}\text { School of } \\
\text { Political Science }\end{array}$ & 676 & 396 & 520 & 4 & 132 & 20 \\
\hline 11 & MT & $\begin{array}{l}\text { College of } \\
\text { Environment } \\
\text { and Natural } \\
\text { Resources }\end{array}$ & 1.681 & 906 & 1.240 & 8 & 366 & 67 \\
\hline 12 & $\mathrm{NN}$ & $\begin{array}{l}\text { College of } \\
\text { Agriculture }\end{array}$ & 4.740 & 2.477 & 3.818 & 14 & 779 & 129 \\
\hline 13 & SP & $\begin{array}{l}\text { School of } \\
\text { Education }\end{array}$ & 1.595 & 1.008 & 1.300 & 12 & 253 & 30 \\
\hline
\end{tabular}


Nguyen Van Hoa

ACTUAL STATUS ASSESSMENT AND SOME RECOMMENDED SOLUTIONS TO IMPROVE

THE EFFICIENCY OF PHYSICAL EDUCATION WORK AT CAN THO UNIVERSITY, VIETNAM

\begin{tabular}{|c|c|c|c|c|c|c|c|c|}
\hline 14 & TD & $\begin{array}{l}\text { Department of } \\
\text { Physical } \\
\text { Education }\end{array}$ & 132 & 31 & 95 & & 31 & 6 \\
\hline 15 & $\mathrm{TN}$ & $\begin{array}{l}\text { College of } \\
\text { Engineering } \\
\text { Technology }\end{array}$ & 7.978 & 1,345 & 6.799 & 34 & 872 & 273 \\
\hline 16 & TS & $\begin{array}{l}\text { College of } \\
\text { Aquaculture } \\
\text { and Fisheries }\end{array}$ & 1.738 & 891 & 1.376 & 7 & 312 & 43 \\
\hline 17 & $\mathrm{XH}$ & $\begin{array}{l}\text { School of Social } \\
\text { Sciences and } \\
\text { Humanities }\end{array}$ & 1.783 & 1,308 & 1.470 & 6 & 252 & 55 \\
\hline \multicolumn{3}{|c|}{ Total I } & 40.882 & 20.313 & 33.157 & 177 & 6.120 & 1.428 \\
\hline \multicolumn{9}{|c|}{ II. Other trainings } \\
\hline 1 & & $\begin{array}{l}\text { Part-time at } \\
\text { school and } \\
\text { localities }\end{array}$ & 4.265 & 1.649 & 4.265 & & & \\
\hline 2 & & $\begin{array}{l}\text { Distance } \\
\text { training }\end{array}$ & 4.082 & 1.749 & 4.082 & & & \\
\hline 3 & & Master's & 2.068 & 994 & 2.068 & & & \\
\hline 4 & & Doctor's & 267 & 120 & 267 & & & \\
\hline 5 & & $\begin{array}{l}\text { Foreign } \\
\text { learners } \\
\text { training }\end{array}$ & 45 & 19 & 45 & & & \\
\hline \multicolumn{3}{|c|}{ Total II } & 10.727 & 3.537 & 10.727 & & & \\
\hline \multicolumn{3}{|c|}{ Total I + II } & 51.609 & 23.850 & 43.884 & & & \\
\hline
\end{tabular}

According to data from Table 1, we can see that:

\section{a. Formal university training}

The University (17 training units) has a very large number of learners and students 51,609 people. Among which, College of Engineering Technology and School of Economics has the largest number of students (7.978 and 6.932 respectively). The number of graduated and graduating-during-summer students is 6,120. Currently, Department of Physical Education is managing 132 student specialized in physical education and have completed the graduation process for 31 students, 06 students have dropped out or transferred.

\section{b. Other trainings}

With 10,727 learners and students, the training resource has shown a big decrease recently. In detail, part-time students at school and localities, along with distance-trained students continuously decreased year by year. Although the training scope has been expanded to the Central and Northern regions, there is still a lack in training target compared to the that allowed by the Ministry of Education and Training. Also, master's and doctoral training has continuously decreased after many years. This indicator is influenced by government agencies which have strictly managed the training needs (need approval from the Department of Home Affairs of the provinces/cities...) 
Department of Physical Education only takes part in training regular students (physical education subject) and specialized classes; the training part-time students is also gradually limited, because there has been a memorandum signed by the University and locality for a coordinate training.

\subsubsection{Actual status of the curriculum for students of the University}

The curriculum is applied for students of the whole University, Department of Physical Education teaches 02 subjects: non-specialized students and students scpecializing in physical education. Basic features of the curriculum are summarized in Table 2.

Table 2: Statistics on physical education work at Can Tho University

\begin{tabular}{|c|c|c|c|c|c|c|}
\hline \multicolumn{4}{|c|}{$\begin{array}{c}\text { Non-Specialized Program } \\
(3 \text { credits }=90 \text { periods }) \\
\text { including } 9 \text { electives }\end{array}$} & \multicolumn{3}{|c|}{$\begin{array}{l}\text { Program Specialized } \\
\text { in Physical Education } \\
\text { (140 credits) including }\end{array}$} \\
\hline No. & Subject & Credits & Classes & Formal & Discipline base & Specialized \\
\hline 1 & Athletics & 3 & 90 & 42 credits & 35 credits & 63 credits \\
\hline 2 & Taekwondo & 3 & 90 & \multirow{8}{*}{$\begin{array}{l}\text { Including the } \\
\text { following } \\
\text { knowledge } \\
\text { group: National } \\
\text { defense, } \\
\text { English, } \\
\text { Informatics, } \\
\text { Education, } \\
\text { Law... }\end{array}$} & \multirow{8}{*}{$\begin{array}{c}\text { Including } \\
\text { specialized } \\
\text { theoretical subjects, } \\
\text { such as: Theory, } \\
\text { Psychology, } \\
\text { Physiology, } \\
\text { Biochemistry, } \\
\text { Neonatology... }\end{array}$} & \multirow{8}{*}{$\begin{array}{c}\text { Including: } \\
\text { Practical } \\
\text { content, Sports, } \\
\text { Pedagogical } \\
\text { Practice, } \\
\text { Pedagogical } \\
\text { practice, } \\
\text { Graduation } \\
\text { thesis... }\end{array}$} \\
\hline 3 & Volleyball & 3 & 90 & & & \\
\hline 4 & Football & 3 & 90 & & & \\
\hline 5 & Badminton & 3 & 90 & & & \\
\hline 6 & Table tennis & 3 & 90 & & & \\
\hline 7 & Aerobics & 3 & 90 & & & \\
\hline 8 & Basketball & 3 & 90 & & & \\
\hline 9 & Chess & 3 & 90 & & & \\
\hline
\end{tabular}

As shown from Table 2, we can see that:

- For the non-specialized physical education program: Can Tho University has developed the physical education program in accordance with the Circular No: 25/2015/TT-BGDĐT of the Ministry of Education and Training "stipulations on physical education programs under university-level training programs" is a minimum of 3 credits and Government Decree No: 11/2015/ND-CP on physical education work. The program at Can Tho University has 03 credits, each credit has 30 classes; including 9 electives. Students choose 01 subject and have to enroll in a fixed course of 3 modules of that subject. In case of changing to another subject, students have to choose from the beginning, or if choosing an alternative subject, they have to be approved and confirmed by the management unit. This program has been established a Satisfactory Evaluation Committee before being put into official teaching;

- For the specialized physical education program: Department of Physical Education focuses on teaching general subjects and specialized subjects that are included in the training program framework. 


\subsubsection{Actual status of the contingent of officials - employees at Can Tho University}

Actual status of the contingent of officials - employees at Can Tho University in the second quarter of 2021 is shown in Table 3.

Table 3: Statistics on the actual status of the contingent of officials - employees at Can Tho University

\begin{tabular}{|c|c|c|c|c|c|c|c|c|c|c|c|}
\hline \multirow[t]{2}{*}{ Unit } & \multicolumn{2}{|c|}{$\begin{array}{l}\text { Officials - } \\
\text { Employees }\end{array}$} & \multirow[t]{2}{*}{ Total } & \multicolumn{4}{|c|}{ Degree } & \multicolumn{3}{|c|}{$\begin{array}{c}\text { Lecturer' } \\
\text { academic rank }\end{array}$} & \multirow[b]{2}{*}{ 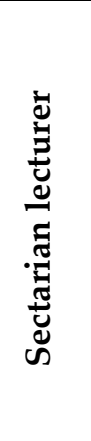 } \\
\hline & $\underset{\circlearrowright}{\grave{Z}}$ & 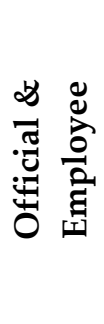 & & 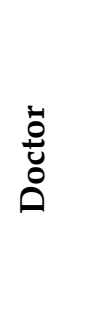 & $\frac{\vec{\Phi}}{\stackrel{\vec{D}}{\tilde{\Sigma}}}$ & 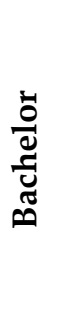 & 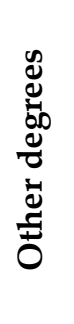 & 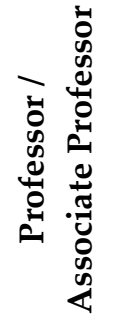 & 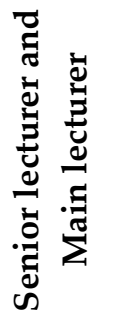 & 离 & \\
\hline $\begin{array}{l}\text { CT } \\
\text { University }\end{array}$ & 1.082 & 727 & 1.809 & 514 & 716 & 392 & 187 & 155 & 272 & 637 & 18 \\
\hline Percentage & 100 & - & - & 47.50 & - & - & - & 14,32 & 25.14 & 58.87 & 1.66 \\
\hline $\begin{array}{l}\text { Department } \\
\text { of physical } \\
\text { education }\end{array}$ & 17 & 03 & 20 & 07 & 10 & 02 & 01 & 0 & 10 & 7 & 0 \\
\hline $\begin{array}{l}\text { Lecturer } \\
\text { percentage }\end{array}$ & 100 & 100 & - & 41.18 & 58.82 & - & - & 0 & 58.82 & 41.18 & - \\
\hline
\end{tabular}

As can be seen from Table 3:

- The number of officials and employees at Can Tho University: 1.809 in total, in which 1,082 are lecturers and 727 are specialists, staff, and assistants... Among the 1,082 lecturers, 514 have doctoral degrees, accounting for $47.50 \%$, the rest have master's degrees, except for 18 seconded instructors from Military Region 9 teaching National Defense \& Security have bachelor's degree. 15 lecturers having professor's degrees and 140 having associate professor degrees make up a percentage of $14.32 \%$; for senior lecturers and main lecturers, there are 272 people which accounts for $25.14 \%$, the rest $58.87 \%$ are 3 rd class lecturers with doctoral and master degrees, 637 people.

- Currently, the number of officials and employees at Department of Physical Education of Can Tho University is 20 people, including 17 lecturers and 03 specialists and staff. Among 17 lecturers, there are 07 with doctoral degrees, accounting for $41.18 \%$; 10 lecturers with master's degrees, accounting for $58.82 \%$ (in which, 04 lecturers are studying postgraduate, not graduated yet). About academic rank: 10 main lecturers accounting for $58,82 \%$ and 07 third class lecturers accounting for $41.14 \%$. The lecturers at Department of Physical Education have achieved $100 \%$ postgraduate qualifications as prescribed by the Ministry of Education and Training. 


\subsubsection{Actual status of sports activities at Can Tho University}

Can Tho University regularly organizes sports activities every year, specifically:

\section{a. Sports activities at school}

- Organizing annual school-wide traditional sports festival (from February to March every year) with about 12 to 15 competing subjects. The festival attracts over 10,000 students and officials to participate. It has really become a good environment for the teaching staffs and students to enjoy healthy entertainment and physical exercise, which is a chance to improve their health.

- Coordinating with the University's Union to organize Can Tho University Union Sports Festival (from October to November every year) with about 7-10 competing subjects. The festival attracts oover 3,000 officials and employees to participate.

- Coordinating with the Department of Women's Public Affairs to organize an annual Volleyball Tournament for officials and employees to celebrate International Women's Day or to celebrate the new academic year.

- Organizing sports competitions for Departments/ Colleges, Institutes; Sports festivals for Associations of provinces/ cities.

b. Tournaments that the university's selected teams participated in, including the following prizes: Regional - Provincial - City - Discipline and Exchange

- In 2018, he Men's - Women's volleyball team participated in the Spring Volleyball Tournament held by the Department of Culture, Sports and Tourism of Can Tho City. The team won the 1st prize for women's and 3rd prize for men's;

- In 2018, joining the movement of Running for Community health, the Department of Physical Education has guided 120 athletes to participate in the cross-country tournament in Can Tho City, winning 3 consolation prizes.

- In 2017, the athletes' delegation (students) from Can Tho University hosted the Vovinam Award of universities and colleges nationwide and achieved the national 3rd prize.

- In 2019, Can Tho University assisted Vietnam Boxing Federation to organize the Boxing tournament.

- In cooperation with the Union of Schools, Can Tho University attended the annual Association Sports Festival among 05 Southern universities.

Students of Can Tho University have formed a team to participate in the 2020 National University Student Football Championship. SV-LEAGUE has won the 2020 Championship trophy. Currently, the organizers are now preparing for the training-andcompeting plan for 2021 Championship (expected in August 2021).

2.2.6 Actual status of facilities, equipment for physical education, and physical activities at Can Tho University

Actual status of facilities, equipment for physical education, and physical activities at Can Tho University. 
Table 4: Actual status of physical facilities for physical education and physical activities at Can Tho University

\begin{tabular}{|c|c|c|c|c|c|c|c|}
\hline \multirow[t]{2}{*}{ No. } & & \multirow{2}{*}{$\begin{array}{c}\text { Total } \\
\text { surface area } \\
\left(\mathrm{m}^{2}\right)\end{array}$} & \multirow[b]{2}{*}{ ن } & \multirow[b]{2}{*}{ 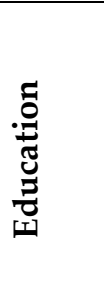 } & \multirow[b]{2}{*}{ 离 } & \multicolumn{2}{|c|}{ Court quality } \\
\hline & & & & & & 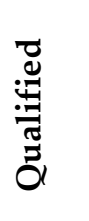 & 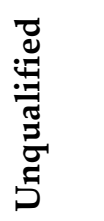 \\
\hline 1 & $\begin{array}{l}\text { Multi-purpose } \\
\text { gymnasium }\end{array}$ & \multirow{9}{*}{$\begin{array}{c}60.844 \mathrm{~m}^{2} \\
\text { (Zone 1, } \\
\text { Zone } 2 \\
\text { and } \\
\text { Hoa An } \\
\text { Zone) }\end{array}$} & 01 & 01 & 01 & 01 & 0 \\
\hline 2 & $\begin{array}{l}\text { Gymnasium for CL, BB, } \\
\text { Martial Arts... }\end{array}$ & & 01 & 01 & 01 & 01 & 0 \\
\hline 3 & $\begin{array}{l}\text { Football pitch }+ \text { running } \\
\text { tracks for athletics }\end{array}$ & & 03 & 01 & 02 & 02 & 01 \\
\hline 4 & Volleyball court & & 15 & 03 & 12 & 3 & 12 \\
\hline 5 & Basketball court & & 01 & 01 & 01 & 01 & 00 \\
\hline 6 & Tennis court & & 01 & 01 & 01 & 01 & 00 \\
\hline 6 & Badminton court & & 10 & 03 & 07 & 05 & 05 \\
\hline 7 & Ping Pong table & & 20 & 06 & 14 & 10 & 10 \\
\hline 8 & $\begin{array}{l}\text { Court and equipment for } \\
\text { physical activities } \\
\text { outdoors }\end{array}$ & & 01 & 00 & 01 & 01 & 00 \\
\hline \multicolumn{2}{|c|}{ Sum } & $60.844 \mathrm{~m}^{2}$ & 53 & 17 & 42 & 25 & 28 \\
\hline
\end{tabular}

Table 4 shows that the total area for physical education and physical activities of Can Tho University is approximately $60.844 \mathrm{~m}^{2}$, includes:

- A 4,965 $\mathrm{m}^{2}$ multi-purpose gymnasium is utilized for competition, education, and practicing (mini football, volleyball, badminton, table tennis, martial arts, shuttlecock).

- A $3.900 \mathrm{~m}^{2}$ covered gymnasium is utilized for education, and practicing (badminton, table tennis, martial arts, shuttlecock).

Annually, Can Tho University allocate funds to repair and construct essential infrastructure for physical education and physical activities for all university lecturers and students, and at the same time, trains teams to participate in the tournaments of city/sector as well as national tournaments.

\subsubsection{Actual status of scientific research in the field of physical education and sports at} Can Tho University

Actual status of scientific research in the field of physical education and sport at Can Tho University is presented in Table 4. 
Table 4: Actual status of scientific research in the field of physical education and sport from 2014 to present at Can Tho University

\begin{tabular}{|c|c|c|c|c|c|c|c|c|}
\hline \multirow{3}{*}{$\begin{array}{l}\text { Academic } \\
\text { year }\end{array}$} & \multirow{3}{*}{ 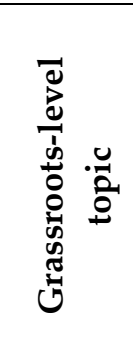 } & \multirow{3}{*}{ 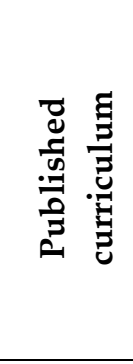 } & \multicolumn{5}{|c|}{ Published articles } & \multirow{3}{*}{ 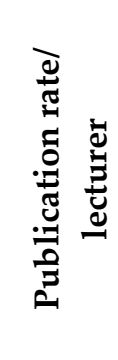 } \\
\hline & & & 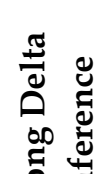 & 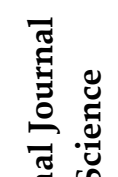 & \multicolumn{2}{|c|}{$\begin{array}{c}\text { International Journal/ } \\
\text { Conference }\end{array}$} & \multirow{2}{*}{ 吾 } & \\
\hline & & & & & Domestic & Foreign & & \\
\hline $2014-2015$ & 0 & 00 & 11 & 01 & 0 & 0 & 12 & 0.67 \\
\hline 2015-2016 & 2 & 0 & 18 & 02 & 0 & 0 & 22 & 1.22 \\
\hline 2016-2017 & 3 & 0 & 17 & 03 & 0 & 0 & 23 & 1.28 \\
\hline 2017-2018 & 5 & 0 & 0 & 24 & 0 & 0 & 29 & 1.61 \\
\hline 2018-2019 & 0 & 0 & 0 & 18 & 01 & 0 & 19 & 1.06 \\
\hline $2019-2020$ & 4 & 0 & 0 & 22 & 02 & 0 & 28 & 1.75 \\
\hline $2020-2021$ & 1 & 3 & 0 & 25 & 0 & 5 & 33 & 1.94 \\
\hline
\end{tabular}

As shown in Table 4, it is obvious that over the past few years, Department of Physical Education of Can Tho University has always been active in scientific research, and has hosted 06 research conferences at regional and national level from 2014 till now, PE teachers have implemented many scientific topics at grassroots level, published many scientific articles in specialized journals, compiled and published teaching curricula in order to improve and improve the quality of training students in the field of physical education. However, only a small number of staff participated in the research activities, despite the fact that the Department of Physical Education has always encouraged and rewarded all lecturers who engage, but it has not mobilized many lecturers. There are still several difficulties and limitations in accessing and publishing international scientific articles.

\subsection{Recommendations for improving the quality of physical education at Can Tho University}

Based on the medium-term development project 2017-2022, the Management Board agreed to implement the orientation to 2030 of the Department of Physical Education, the orientations on implementation solutions are related to 05 groups of practice mentioned above, specifically:

\subsubsection{Solutions for training at Can Tho University}

\section{a. Concerning the training for students majoring in physical education}

Continue doing good work in annual enrollment, coordinate with Youth Newspaper to organize enrollment counseling days and enrollment counseling through various online formats to maintain the number of matriculated candidates according to the targets of the Ministry of Education and Training; 
Periodically review the training curriculum once every 2 years to improve it. Based on feedback from employers and alumni, improve the content of output standards and appropriate assessment, and gradually increase training quality;

Organize assessment outside the training program for students majoring in physical education based on the 2021 set of requirements of Ministry of Education and Training, hence, develop a master's training project in the field of physical education from 2022 onwards;

\section{b. Concerning the teaching of physical education for non-specialized students}

Continue to investigate the need to study elective subjects (in addition to the 9 subjects that have been taught), to open more suitable sports, and contribute to diversifying students' learning demands;

Continue to examine the pedagogy of the Physical fitness tests in accordance with Decision No. 53/Ministry of Education and Training, gather essential information to develop exercises that fulfill the Ministry of Education and Training's physical fitness criteria;

\subsubsection{Solutions for developing the PE teaching staff at Can Tho University}

Continue to recruit and train lecturers in order to meet the training requirements of the University, (submit a plan to the School Council and the Board of Management for recruitment decisions in the upcoming years, prioritizing lecturers with doctoral degrees; Sending master lecturers to conduct doctoral training and train short as well as mediumterm courses for professional work);

Mobilize lecturers to accomplish the goal-striving process following the University's regulations, improve academic ranks - degrees, particularly being qualified to be professors or associate professors;

\subsubsection{Solutions for the movement of physical activities at Can Tho University}

Continue to hold traditional physical activities for staff and students; encourage staff and students to be more aware of health training and participate in physical activities in the School and the community;

Continue to participate in regional, provincial, and sectoral sports tournaments and strengthen the bond with southern universities;

Recommend the Vietnam University Sports Association to consolidate the Executive Committee of the University Sports Association in Mekong Delta to reorganize the regional physical activities;

\subsubsection{Solutions for facilities and equipment for physical education and physical activities at Can Tho University}

Maintain good facility management (repair, procurement, operation, and maintenance) from frequent expenditure and proposed funding sources allocated by the University, ensuring teaching and organizing physical activities; 
Propose the University for the investment in substantial projects: Swimming pool, artificial turf, synthetic track for athletics...

\subsubsection{Scientific research solutions in the field of physical education and physical activities at Can Tho University}

Bond with prestigious universities and similar sectors to exchange, learn and access new knowledge for innovation and experience in scientific research.

Suggest the University authorize funding for National Scientific Research Conference once a year; thereby strengthening the research capacity of lecturers, aiming to publish articles with international indexes (ISI or Scopus) to upgrade the academic status of lecturers; register scientific research works, such as grassroots, local level projects to ministerial level one.

Register in the compilation of textbooks, monographs, reference books, etc. that help to improve the training process.

\section{Conclusion}

On the basis of assessing the current situation and recommendations for improving the efficiency of PE at Can Tho University, I have reached the following conclusions:

A. In recent years, actual status of physical education at Can Tho University has evolved in the following areas:

- Can Tho University is a multidisciplinary university (with 109 disciplines) which educates a vast number of students. With over 50,000 students of 17 training units. Can Tho University has undergone 14 years of training under the credit system; the PE program for all students consists of 03 credits, with 9 elective sports (each sport includes 03 credits and 90 lessons);

- The work of holding physical activities is carried out regularly;

- The staff has increasingly improved their qualifications in terms of academic titles and degrees;

- Facilities for teaching and organizing sports and physical activities are increasingly refined to assist the teaching process as well as organize sports and physical activities; however, it lacks other necessary works, such as running track, artificial turf, swimming pool, etc.

- The rise in the quantity and quality of scientific research-related articles seems positive. However, there are still limitations on the number of lecturers participating in scientific research and limitations in accessing and publishing international articles (ISI or Scopus).

B. In an effort to improve the effectiveness of PE work at Can Tho University in the upcoming years, the Department of General Education will continue to implement 15 solutions from 05 content groups that are considered as short-term and medium-term resolutions to transform the Department of Physical Education into Faculty of Physical 
Education to merit its position as a member of an excellent university in Mekong Delta region and across the country.

\section{Conflict of Interest Statement}

The author declares no conflicts of interests.

\section{About the Author}

Nguyen Van Hoa has been a physical education teacher at Can Tho University, Vietnam.

\section{References}

Ministry of Education and Training (2015), Circular No. 25/2015/TT-BGDĐT Regulations on PE courses in university-level training programs.

Ministry of Education and Training (2012), Summary report on physical education and the Phu Dong Competition in high schools from 2008 to 2012, Can Tho, August 2012.

Ministry of Education and Training (2019), Official Letter No. 3833/BGDĐT-GDTC, Guidelines for the implementation of physical education, sports, and school health responsibilities throughout the 2019-2020 school year.

Government (2015), Decree No. 11/2015/ND-CP of the Government on January 31, 2015, Regulations on physical education and sports activities in schools.

Government (2016), Decision No. 1076/QD-TTg of the Prime Minister on June 17, 2016, about the approval of the general project for the Development of Physical Education and School Sports in the 2016-2020 period and orientation towards 2025.

Hoang Ha (2016), Research on solutions to improve the quality of physical education in member schools of Vietnam National University, Ho Chi Minh City, Doctoral thesis in education, Institute of Sports Science, Hanoi.

National Assembly (2019), Law No. 43/2019/QH14, promulgated in Hanoi, June 14, 2019.

Can Tho University (2021), https://dap.ctu.edu.vn/so-lieu-thon/78-so-lieu-thong-ke-quy3-2029.html

Can Tho University (2021), https://qldiem.ctu.edu.vn/htql/quanly/qlsv/codes/index.php?mID=SV401

Can Tho University (2021), https://dpe.ctu.edu.vn/images/upload/daotao/TD40.pdf 
Creative Commons licensing terms

Authors will retain the copyright of their published articles agreeing that a Creative Commons Attribution 4.0 International License (CC BY 4.0) terms will be applied to their work. Under the terms of this license, no permission is required from the author(s) or publisher for members of the community to copy, distribute, transmit or adapt the article content, providing a proper, prominent and unambiguous attribution to the authors in a manner that makes clear that the materials are being reused under permission of a Creative Commons License. Views, opinions and conclusions expressed in this research article are views, opinions and conclusions of the author(s). Open Access Publishing Group and European Journal of Physical Education and Sport Science shall not be responsible or answerable for any loss, damage or liability caused in relation to/arising out of conflict of interests, copyright violations and inappropriate or inaccurate use of any kind content related or integrated on the research work. All the published works are meeting the Open Access Publishing requirements and can be freely accessed, shared, modified, distributed and used in educational, commercial and non-commercial purposes under a Creative Commons attribution 4.0 International License (CC BY 4.0). 